\title{
DATA QUALITY OBJECTIVES FOR SELECTING WASTE SAMPLES FOR THE BENCH STEAM REFORMER TEST
}

\section{L. Banning}

Washington River Protection Solutions LLC

Richland, WA 99352

U.S. Department of Energy Contract DE-AC27-08RV14800

$\begin{array}{lll}\text { EDT/ECN: } & \text { DRF } & \text { UC: N/A } \\ \text { Cost Center: } & \text { 2GB00 } & \text { Charge Code: } \\ \text { B\&R Code: } & \text { N/A } & \text { Total Pages: } 15\end{array}$

Key Words: Data Quality Objective, DQO Fluid Bed Steam Reformer, FBSR, Analysis, Archived Samples.

Abstract: This document describes the data quality objectives to select archived samples located at the 222-S Laboratory for Fluid Bed Steam Reformer testing. The type, quantity and quality of the data required to select the samples for Fluid Bed Steam Reformer testing are discussed.

TRADEMARK DISCLAIMER. Reference herein to any specific commercial product, process, or service by trade name, trademark, manufacturer, or otherwise, does not necessarily constitute or imply its endorsement, recommendation, or favoring by the United States Government or any agency thereof or its contractors or subcontractors.

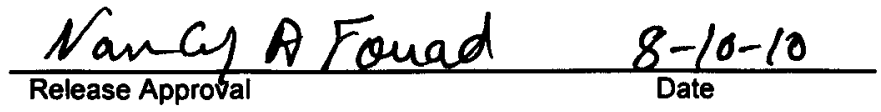

Approved For Public Release

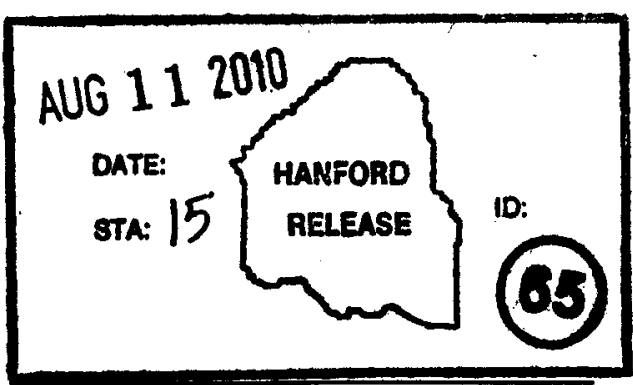

Release Stamp 


\begin{tabular}{|c|c|c|c|}
\hline \multicolumn{2}{|r|}{$\begin{array}{l}\text { Tank Operations Contractor (TOC) } \\
\text { RECORD OF REVISION }\end{array}$} & $\begin{array}{l}\text { (1) Document Number: } \\
\text { RPP-47073 }\end{array}$ & Page 1 \\
\hline \multicolumn{4}{|c|}{$\begin{array}{l}\text { (2) Title: } \\
\text { Data Quality Objectives for Selecting Waste Samples for the Bench Steam Reformer Test }\end{array}$} \\
\hline \multicolumn{4}{|c|}{ Change Control Record } \\
\hline \multirow{2}{*}{$\begin{array}{c}\text { (3) } \\
\text { Revision }\end{array}$} & \multirow{2}{*}{ (4) Description of Change - Replace, Add, and Delete Pages } & \multicolumn{2}{|c|}{ Authorized for Release } \\
\hline & & (5) Resp. Engr. (printsign/date) & (6) Resp. Mgr. (print/sign/date) \\
\hline 0 & Released with DRF on 8-3-10 & D. L. Banning & J. G. Reynolds \\
\hline $1 R 8$ & Complete revision. Released with DRF. & D. L. Banning 8 DL Tamin & 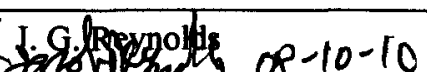 \\
\hline & & & \\
\hline & & & \\
\hline & & & \\
\hline & & & \\
\hline & & & \\
\hline & & & \\
\hline & & & \\
\hline & & & \\
\hline & & & \\
\hline & & & \\
\hline & & & \\
\hline & & & \\
\hline & & & \\
\hline & & & \\
\hline & & & \\
\hline & & & \\
\hline & & & \\
\hline
\end{tabular}


RPP-47073

Revision 1

\section{DATA QUALITY OBJECTIVES FOR SELECTING WASTE SAMPLES FOR THE BENCH STEAM REFORMER TEST}

\section{L. Banning}

Washington River Protection Solutions

Date Published

August 2010

\section{washington river}

protectionsolutions

Post Office Box 850

Richland, Washington

Prepared for the U.S. Department of Energy Office of River Protection

Approved for public release; distribution unlimited 


\section{TABLE OF CONTENTS}

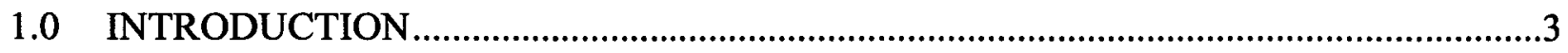

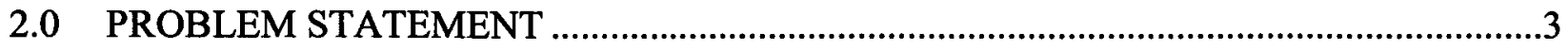

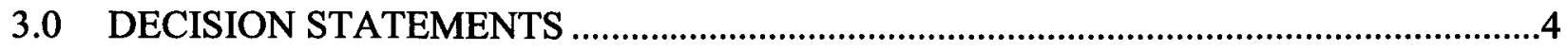

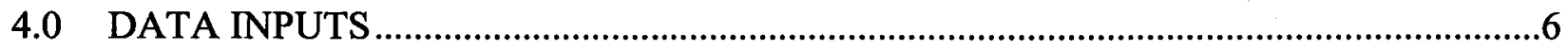

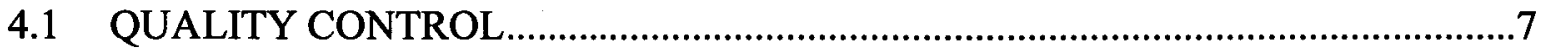

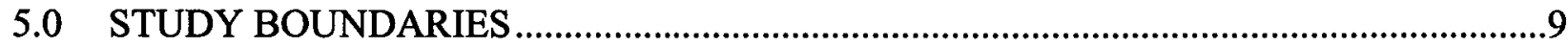

5.1 SPATIAL AND TEMPORAL BOUNDARIES ………............................................10

5.2 SAMPLING CONSTRAINTS .........................................................................

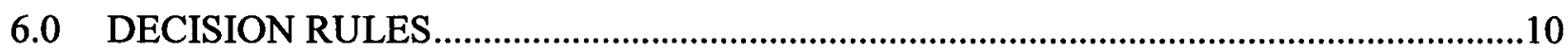

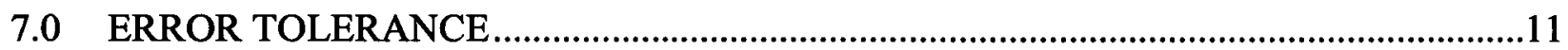

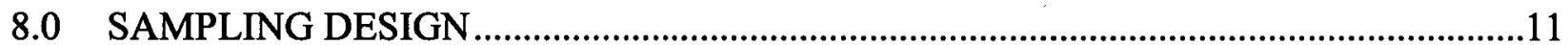

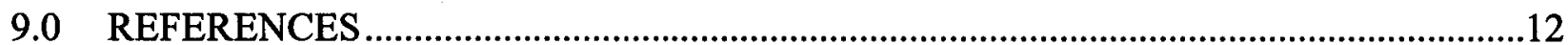

\section{LIST OF FIGURES}

Figure 3-1. Sample Selection Logic Flow Chart 5

\section{LIST OF TABLES}

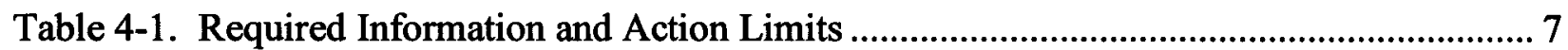

Table 4-2. Quality Control Parameters. .................................................................................. 9

\section{LIST OF TERMS}
Abbreviations and Acronyms
BSR bench steam reformer
DQO data quality objectivePSQ principle study questions
QA quality assurance
TRU transuranic 


\subsection{INTRODUCTION}

In order to maximize the efficiency and minimize the time to treat Hanford tank waste in the Waste Treatment and Immobilization Plant, additional treatment processes may be required. One of the potential treatment processes is the fluid bed steam reformer. A determination of the adequacy of the fluid bed steam reformer process to treat Hanford tank waste is required. The initial step in determining the adequacy of the fluid bed steam reformer process is to select archived waste samples from the 222-S Laboratory that will be used in a bench scale test. Analyses of the selected samples will be required to confirm the samples meet the shipping requirements and for comparison to the bench steam reformer (BSR) test product.

This document describes the Data Quality Objective (DQO) process undertaken to ensure appropriate samples are selected to support BSR testing. The DQO process was implemented in accordance with TFC-ENG-CHEM-C-16, Data Quality Objectives for Sampling and Analyses and the U.S. Environmental Protection Agency EPA QA/G4, Guidance on Systematic Planning Using the Data Quality Objectives Process. As stated in these documents, the DQO process is iterative. Therefore, changes to this DQO document will be made during the project if data are obtained that change the requirements or if additional requirements or data are needed. As the BSR testing proceeds and data to support the testing are obtained, specific constituents for analysis can be added or deleted from the document as required.

In addition to this DQO document, other documents will be prepared to guide the overall testing program including test plans for the sample preparation and analysis, sample selection using existing data, BSR testing, and the subsequent analysis of samples.

\subsection{PROBLEM STATEMENT}

The objective of a problem statement is to clearly define the problem (the reason analytical data are required) so the focus of the project (selecting archived waste samples for the BSR testing) will be unambiguous.

With the objective of the problem statement and the focus of this DQO process in mind the problem statement can be written as follows:

Select appropriate archived samples from the 222-S Laboratory that meet the requirements for shipping, BSR testing, and BSR product analyses.

The primary study question developed from the problem statement can be stated as:

Can the archived samples selected from the 222-S Laboratory meet the radionuclide requirements for shipping, BSR testing, and BSR product analyses? 


\subsection{DECISION STATEMENTS}

Decision statements are developed by combining principle study questions (PSQ) with alternative actions. The PSQ identifies key unknown conditions or unresolved issues that reveal the solution to the problem. Alternative actions are the possible actions that might be taken once a PSQ has been resolved.

The decision statement is as follows:

Determine whether the selected archived samples from the 222-S Laboratory meet the radionuclide requirements for shipping, BSR testing, BSR product analytical requirements and can be shipped or requires additional radionuclide removal, or requires no action.

Figure 3-1 shows the general logic flow chart for selecting Hanford waste samples for the BSR testing. The flow chart shows the decisions and activities covered by this DQO document needed to address sample selection for BSR testing. 
Figure 3-1. Sample Selection Logic Flow Chart

u

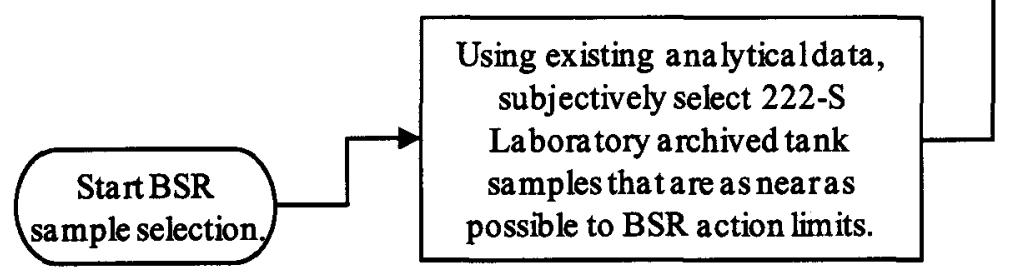

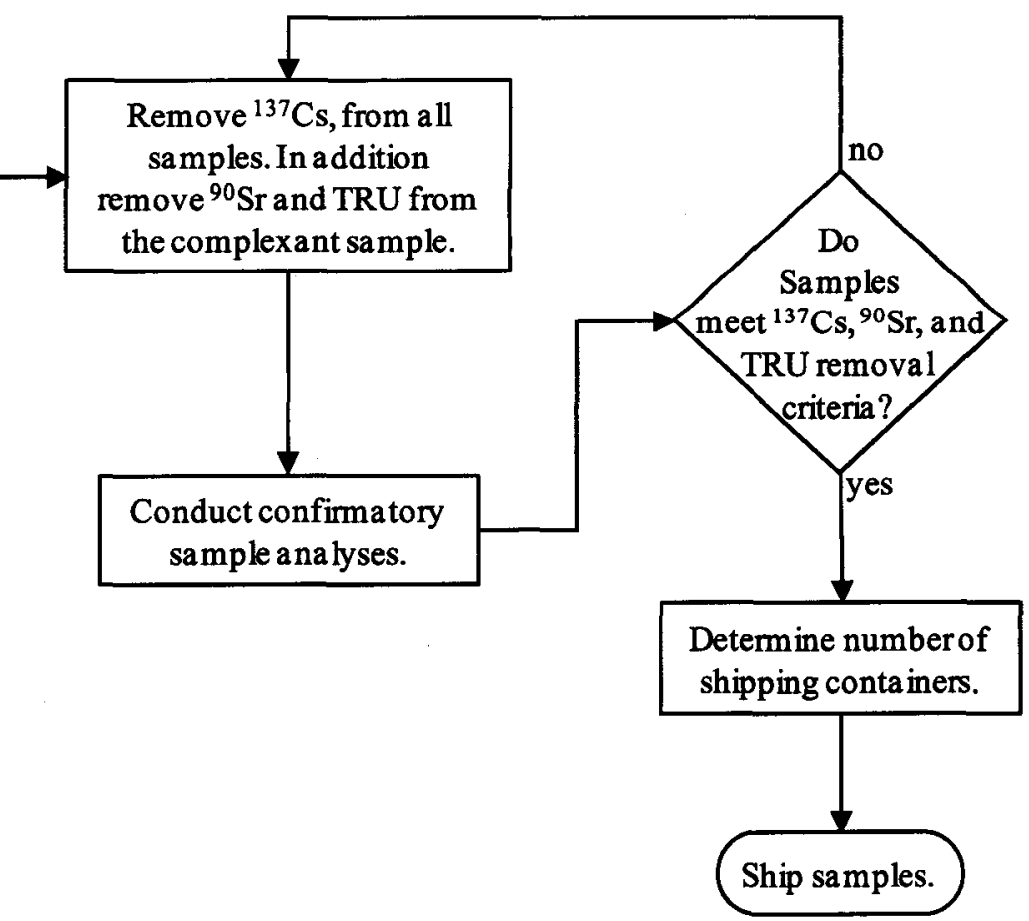




\subsection{DATA INPUTS}

Three separate samples, with different properties, will be shipped for BSR testing. Each one of the three samples may be made up of several 222-S Laboratory archived samples from the same tank. The shipped samples will be liquid; however, the samples may be made from dissolved archived solid samples. The general requirements for each of the three samples are shown below.

1. Contains high $\mathrm{SO}_{4}{ }^{2-}$ (sulfate), $\mathrm{Cl}^{-}$(chloride), $\mathrm{F}^{-}$(fluoride), and $\mathrm{PO}_{4}{ }^{3-}$ (phosphate) relative to $\mathrm{Na}$ (sodium),

2. Contains low $\mathrm{SO}_{4}{ }^{2-}, \mathrm{Cl}^{-}, \mathrm{F}^{-}$, and $\mathrm{PO}_{4}{ }^{3-}$ relative to $\mathrm{Na}$, and

3. Complexant waste.

As can be seen in Figure 3-1, the samples will be selected from the 222-S Laboratory using existing data. The selection process will be based on the information in RPP-RPT-47143, Sample Selection Recommendations for Fluid Bed Steam Reforming Treatability Studies Using Hanford Low Activity Waste Underground Storage Tank Samples. The samples will be subjectively selected to match, as near as possible, the anion $\left(\mathrm{SO}_{4}{ }^{2-}, \mathrm{Cl}^{-}, \mathrm{F}^{-}\right.$, and $\mathrm{PO}_{4}{ }^{3-}$ ) action limits shown in Table 4-1. Because samples may not be available that meet the action limits, a prioritization of the anions was determined. The order of importance for meeting the action limits is $\mathrm{SO}_{4}{ }^{2-}, \mathrm{Cl}^{-}, \mathrm{F}^{-}$, and $\mathrm{PO}_{4}{ }^{3-}$.

After the samples have been selected, ${ }^{137} \mathrm{Cs}$ (cesium 137) will be removed from the samples. In addition, ${ }^{90} \mathrm{Sr}$ (strontium 90 ) and transuranic (TRU) constituents will be removed from the complexant sample. The samples will be analyzed to confirm removal of ${ }^{137} \mathrm{Cs},{ }^{90} \mathrm{Sr}$, and TRU constituents to the action limits shown in Table 4-1 and for information required for shipping. In addition to the radionuclides, analyses of the analytes listed in Table 4-1 will be conducted at this time. These analyses will be conducted for information and will be compared to the BSR test product. 
Table 4-1. Required Information and Action Limits

\begin{tabular}{|c|c|c|}
\hline Data Inputs & Action Limits & Comments \\
\hline $\mathrm{Na}$ & $\geq 100$ grams per sample & \\
\hline $\mathrm{SO}_{4}{ }^{2-}$ & $\begin{array}{l}\text { High Sample } \geq 0.03 \\
\text { Low Sample } \leq 0.006\end{array}$ & The action limits are ratios of $\mathrm{SO}_{4}{ }^{2-} \underline{\mathrm{M}} / \mathrm{Na} \underline{\mathrm{M}}$. \\
\hline $\mathrm{Cl}^{-}$ & $\begin{array}{l}\text { High Sample } \geq 0.017 \\
\text { Low Sample } \leq 0.006\end{array}$ & The action limits are ratios of $\mathrm{Cl}^{-} \underline{\mathrm{M}} / \mathrm{Na} \underline{\mathrm{M}}$. \\
\hline $\mathbf{F}^{-}$ & $\begin{array}{l}\text { High Sample } \geq 0.05 \\
\text { Low Sample } \leq 0.004\end{array}$ & The action limits are ratios of $\mathrm{F}^{-} \underline{\mathrm{M}} / \mathrm{Na} \underline{\mathrm{M}}$. \\
\hline $\mathrm{PO}_{4}{ }^{3-}$ & $\begin{array}{l}\text { High Sample } \geq 0.035 \\
\text { Low Sample } \leq 0.005\end{array}$ & The action limits are ratios of $\mathrm{PO}_{4}{ }^{3-} \underline{\mathrm{M}} / \mathrm{Na} \underline{\mathrm{M}}$. \\
\hline${ }^{137} \mathrm{Cs}$ & $<1.5 \mu \mathrm{Ci} / \mathrm{g}$ & \\
\hline${ }^{90} \mathrm{Sr}$ & $<400 \mu \mathrm{Ci}$ per sample & \\
\hline $\begin{array}{c}\text { TRU constituents } \\
\left({ }^{241} \mathrm{Am},{ }^{243} \mathrm{Am}{ }^{237} \mathrm{~Np},{ }^{239} \mathrm{Pu}\right. \\
\end{array}$ & $<100 \mathrm{nCi} / \mathrm{g}$ & $\begin{array}{l}{ }^{243} \mathrm{Cm},{ }^{244} \mathrm{Cm} \text {, and }{ }^{238} \mathrm{Pu} \text {, are not included due } \\
\text { to analytical methods being used. }\end{array}$ \\
\hline $\begin{array}{c}{ }^{229} \mathrm{Th},{ }^{230} \mathrm{Th},{ }^{232} \mathrm{Th},{ }^{231} \mathrm{~Pa}, \\
{ }^{233} \mathrm{U},{ }^{234} \mathrm{U},{ }^{235} \mathrm{U},{ }^{236} \mathrm{U},{ }^{238} \mathrm{U},\end{array}$ & None & Required information for shipping. \\
\hline${ }^{99} \mathrm{Tc}$ & None & $\begin{array}{l}\text { Information only. Knowledge of amount in the } \\
\text { samples is needed for testing; however, no } \\
\text { limits are required to ship the sample. } \\
\end{array}$ \\
\hline TOC & None & $\begin{array}{l}\text { Information only. Knowledge of amount in the } \\
\text { samples is needed for testing; however, no } \\
\text { limits are required to ship the sample. }\end{array}$ \\
\hline $\begin{array}{c}\text { RCRA metals } \\
(\mathrm{Ag}, \mathrm{As}, \mathrm{Ba}, \mathrm{Be}, \mathrm{Cd}, \mathrm{Cr}, \mathrm{Hg} \\
\mathrm{Pb}, \mathrm{Ni}, \mathrm{Sb}, \mathrm{Se}, \mathrm{Tl}, \mathrm{V}, \mathrm{Zn})\end{array}$ & None & $\begin{array}{l}\text { Information only. Knowledge of amount in the } \\
\text { samples is needed for testing; however, no } \\
\text { limits are required to ship the sample. } \\
\end{array}$ \\
\hline Sample mass & $<1000 \mathrm{~kg}$ & Limit for treatability studies. ${ }^{(a)}$ \\
\hline $\begin{array}{l}\text { TRU }=\text { transuranic } \\
\text { TOC }=\text { total organic car } \\
\text { RCRA = Resource Cons } \\
\underline{M}=\text { moles }\end{array}$ & ervation and Recovery Act & \\
\hline
\end{tabular}

\subsection{QUALITY CONTROL}

Laboratories and/or subcontracted laboratories performing analyses in support of this DQO document shall have approved and implemented quality assurance (QA) plans. These QA plans shall meet DOE/RL-96-68, Hanford Analytical Services Quality Assurance Requirements Documents (HASQARD) minimum requirements as the baseline for laboratory quality systems. ATL-MP-1011, ATL Quality Assurance Project Plan for 222-S Laboratory specifies the analyses conducted at the 222-S Laboratory. Analyses performed by WRPS shall be performed by ATSMP-1032, 222-S Laboratory Quality Assurance Plan. 
If subcontracting any portion of this DQO to a commercial laboratory off the Hanford Site, the Subcontractor's implementing quality assurance program shall comply with the Department of Energy Consolidated Audit Program (DOECAP) Quality Systems for Analytical Services.

Each sample in the analytical batch will require duplicate analysis; therefore, each client sample will have a primary and duplicate value for each analyte. Other laboratory quality control will be conducted according to the criteria outlined in Table 4-2.

The preferred methods of analysis are SW-846, Test Methods for Evaluating Solid Waste, Physical/Chemical Methods, or other approved standardized methods. The most recent revisions are preferred. Conditions (e.g., quality problems) that do not conform to requirements specified in this DQO or references herein shall be controlled to prevent inadvertent use. These quality problems shall be identified, documented, controlled, and reported to prevent reoccurrence as required by ATL-312, ATL Analytical Project Process Flow procedure (Section 4.26) and ATS 310, 222-S Analytical Project Process Flow procedure (Section 1.25) parts 4.17, 4.18 and 4.19. Off-site laboratories shall initiate their corrective action process as applicable to DOECAP.

The radionuclide analyses will require a turnaround time of four working days. This short turnaround time governs the analytical methods that can be used for radionuclide analyses. The analyses, other than radionuclides, will require a turnaround time of ten working days. After a QA review, the analytical data will be reported by a data summary report. 
Table 4-2. Quality Control Parameters.

\begin{tabular}{|c|c|c|c|c|c|}
\hline \multirow[b]{2}{*}{ Analytes } & \multicolumn{5}{|c|}{ Quality Control Acceptance Criteria } \\
\hline & \begin{tabular}{|c|} 
Proposed Analytical \\
Methods
\end{tabular} & $\begin{array}{c}\text { LCS } \\
\text { \% Recovery } \\
\text { (a) }\end{array}$ & $\begin{array}{c}\text { Spike } \\
\% \text { Recovery }^{(b)}\end{array}$ & $\begin{array}{l}\text { Duplicate RPD } \\
\text { Liquids }\end{array}$ & \begin{tabular}{|c} 
Duplicate RPD \\
Solids
\end{tabular} \\
\hline $\begin{array}{c}\mathrm{Ag}, \mathrm{As}, \mathrm{Ba}, \mathrm{Be}, \mathrm{Cd}, \mathrm{Cr} \\
\mathrm{Hg}, \mathrm{Pb}, \mathrm{Na}, \mathrm{Ni}, \mathrm{Sb}, \mathrm{Se}, \mathrm{Tl} \\
\text { V, } \mathrm{Zn}\end{array}$ & ICP/AES & $80-120$ & $75-125$ & $\leq 20 \%$ & $\leq 30 \%$ \\
\hline $\mathrm{Hg}$ & CVAA & $80-120$ & $75-125$ & $\leq 20 \%$ & $\leq 30 \%$ \\
\hline $\mathrm{Cl}^{-}, \mathrm{F}^{-}, \mathrm{PO}_{4}{ }^{3-}, \mathrm{SO}_{4}{ }^{2-}$ & IC & $80-120$ & $75-125$ & $\leq 20 \%$ & $\leq 30 \%$ \\
\hline${ }^{90} \mathrm{Sr}$ & Beta Counting & $80-120$ & $\mathrm{~N} / \mathrm{A}^{(\mathrm{d})}$ & $\leq 20 \%$ & $\leq 30 \%$ \\
\hline $\begin{array}{l}{ }^{241} \mathrm{Am},{ }^{243} \mathrm{Am},{ }^{238} \mathrm{Pu},{ }^{239} \mathrm{Pu}, \\
{ }^{240} \mathrm{Pu},{ }^{242} \mathrm{Pu},{ }^{244} \mathrm{Pu},{ }^{237} \mathrm{~Np}, \\
{ }^{229} \mathrm{Th},{ }^{230} \mathrm{Th},{ }^{232} \mathrm{Th},{ }^{231} \mathrm{~Pa}, \\
{ }^{233} \mathrm{U},{ }^{234} \mathrm{U},{ }^{235} \mathrm{U},{ }^{236} \mathrm{U},{ }^{238} \mathrm{U},\end{array}$ & ICP/MS & $80-120^{(\mathrm{e})}$ & $75-125^{(\mathrm{e})}$ & $\leq 20 \%$ & $\leq 30 \%$ \\
\hline${ }^{99} \mathrm{Tc}$ & Liquid Scintillation & $80-120$ & $75-125$ & $\leq 20 \%$ & $\leq 30 \%$ \\
\hline${ }^{137} \mathrm{Cs}$ & GEA & $80-120$ & $N / A^{(f)}$ & $\leq 20 \%$ & $\leq 30 \%$ \\
\hline TOC & $\begin{array}{c}\text { Silver catalyzed } \\
\text { persulfate oxidation }\end{array}$ & $80-120$ & $75-125$ & $\leq 20 \%$ & $\leq 30 \%$ \\
\hline
\end{tabular}

Notes:

N/A = Not Applicable

TOC $=$ total organic carbon

(a) LCS = Laboratory Control Sample. This sample is carried through the entire method. The accuracy of a method is usually expressed as the percent recovery of the LCS. The LCS is a matrix with known concentration of analytes processed with each preparation and analyses batch. It is expressed as percent recovery; i.e., the amount measured, divided by the known concentration, times 100 .

(b) For some methods, the sample accuracy is expressed as the percent recovery of a matrix spike sample. It is expressed as percent recovery; i.e., the amount measured, less the amount in the sample, divided by the spike added, times 100 . One matrix spike is performed per analytical batch. Samples are batched with similar matrices.

(c) RPD = Relative Percent Difference between the analytical samples. Analytical precision is estimated by analyzing duplicates taken separately through preparation and analysis. RPD for PCBs may be calculated using matrix spike and matrix spike duplicate results. Acceptable analytical precision is usually $\leq 20 \%$ RPD for liquids and $\leq 30 \%$ for solids if the sample result is at least 10 times the instrument detection limit. $\mathrm{RPD}=(($ absolute difference between primary and duplicate $) /$ mean $) \times 100$

(d) Matrix spike analyses are not required for this method because a carrier or tracer is used to correct for constituent loss during sample preparation and analysis. The result generated using the carrier or tracer accounts for any inaccuracy of the method on the matrix. The reported results reflect this correction.

(e) The measurement is a direct reading of the energy and the analysis is not affected by the sample matrix; therefore, a matrix spike is not required.

(f) Standards are only available for the following analytes ${ }^{241} \mathrm{Am},{ }^{239} \mathrm{Pu},{ }^{237} \mathrm{~Np},{ }^{232} \mathrm{Th},{ }^{235} \mathrm{U}$, and ${ }^{238} \mathrm{U}$.

\subsection{STUDY BOUNDARIES}

This step in the DQO process defines the spatial and temporal boundaries for the required sampling and analyses needed to make the necessary decisions. The spatial boundaries define the physical area to which the decisions will apply and where the samples should be taken. The temporal boundaries describe the timeframe the data will represent, and when the samples should be taken. In addition, this portion of the DQO addresses any sampling constraints. 


\subsection{SPATIAL AND TEMPORAL BOUNDARIES}

Presently, the spatial boundaries for this DQO include only the archived samples (liquid and solid) of Hanford tank waste located at the 222-S Laboratory.

This DQO will be in effect until the BSR testing is concluded and no additional sample selection is required.

\subsection{SAMPLING CONSTRAINTS}

The biggest constraint to obtaining the required samples is the availability of appropriate waste (quantity and type) in the 222-S Laboratory. However, as stated in Section 4.0, each one of the samples to be shipped may be made up of several 222-S Laboratory archived samples from the same tank.

\subsection{DECISION RULES}

The DQO process includes development of decision rules, which define the actions to be taken as a result of exceeding an action limit. Decision rules are expressed as "if...then" statements that incorporate, as available, the parameter of interest, the scale of decision making, the action limit, and the actions that would result from resolution of the decision rule.

Commonly, an action limit is a concentration at which point a predetermined action is taken depending on whether the results of the analyses are above or below the specified action limit. To account for uncertainty in the data, analytical results are compared to the action limit at a statistical confidence interval previously agreed upon. In the case of this DQO, the means of the analytical data (primary and duplicate) are considered adequate to make the comparison to the action limits shown in Table 4-1 and no additional statistical calculations are required.

As can be seen in Figure 3-1, the initial sample selection is made using existing data guided by RPP-RPT-47143. Therefore, only one decision (see Figure 3-1) is made with new analytical data. The decision rule addresses the requirement to remove radionuclides from the samples prior to shipment. Additional informational data are needed to address shipping requirements.

The decision rule is written as follows.

If the average of the confirmatory analytical data for the radionuclide removal meets the action limits (see Table 4-1), then the samples can be shipped; otherwise, repeat the radionuclide removal process until the action limits are met. 


\subsection{ERROR TOLERANCE}

The uncertainty in the DQO process provides an evaluation of the probability of decision error based on an estimation of the mean, variance, and number of samples. The uncertainty evaluation is used to assess the accuracy and precision specified for sample collection and analysis, the level of decision error, and the number of samples required to meet a given decision error rate.

As stated in Section 6.0, the project team determined the means of the analytical data (primary and duplicate) are adequate to make the comparison to the action limits shown in Table 4-1. Therefore, if the mean of the analytical data meets the appropriate action limits or if a subjective determination is made that the sample is suitable for testing then the samples can be used and no additional error calculations will be required.

\subsection{SAMPLING DESIGN}

Sampling for this DQO consists of selecting archived tank waste samples from the 222-S Laboratory. Three samples will be selected and shipped for BSR testing. The sample selection will be based on previous analytical data and sufficient quantity for BSR testing. Each BSR test sample will be from the same tank. However, separate archived samples from the same tank may be combined to provide a sufficient quantity for the test sample.

As stated in Section 4.0, one of the samples selected will be complexant waste. This sample should be obtained from a tank containing complexant waste (e.g., tank 241-AN-107).

Because of the nature of "sampling" for this DQO, sample optimization is not applicable. Sample collection will be based on the criteria shown in Table 4-1. 


\subsection{REFERENCES}

ATL-MP-1011, ATL Quality Assurance Project Plan for 222-S Laboratory, as revised, Advanced Technologies and Laboratories International, Inc., Richland, Washington.

ATL-312, ATL Analytical Project Process Flow, as revised, Advanced Technologies and Laboratories International, Inc., Richland, Washington.

ATS-MP-1032, 222-S Laboratory Quality Assurance Plan, as revised, Washington River Protection Solutions LLC, Richland, Washington.

ATS 310, 222-S Analytical Project Process Flow, as revised, Washington River Protection Solutions LLC, Richland, Washington.

DOECAP, Consolidated Audit Program Quality Systems For Analytical Services Document, as revised, U.S. Department of Energy, Oak Ridge Office, Oak Ridge, Tennessee.

DOE/RL-96-68, 2007, Hanford Analytical Services Quality Assurance Requirements Documents, Rev. 3, U.S. Department of Energy, Richland Operations Office, Richland, Washington.

EPA QA/G-4, 2006, Guidance on Systematic Planning Using the Data Quality Objectives Process, U.S. Environmental Protection Agency Quality Assurance Management Staff, Washington, D.C.

RPP-RPT-47143, 2010, Sample Selection Recommendations for Fluid Bed Steam Reforming Treatability Studies Using Hanford Low Activity Waste Underground Storage Tank Samples, Rev. 0, Washington River Protection Solutions LLC, Richland, Washington.

SW-846, 1986, Test Methods for Evaluating Solid Waste, Physical/Chemical Methods, Third Edition, as amended, U.S. Environmental Protection Agency, Washington, D.C.

TFC-ENG-CHEM-C-16, Data Quality Objectives for Sampling and Analyses, as revised, Washington River Protection Solutions LLC, Richland, Washington.

WAC 173-303-071, "Excluded Categories of Waste," Washington Administrative Code, as amended. 


\section{DISTRIBUTION SHEET}

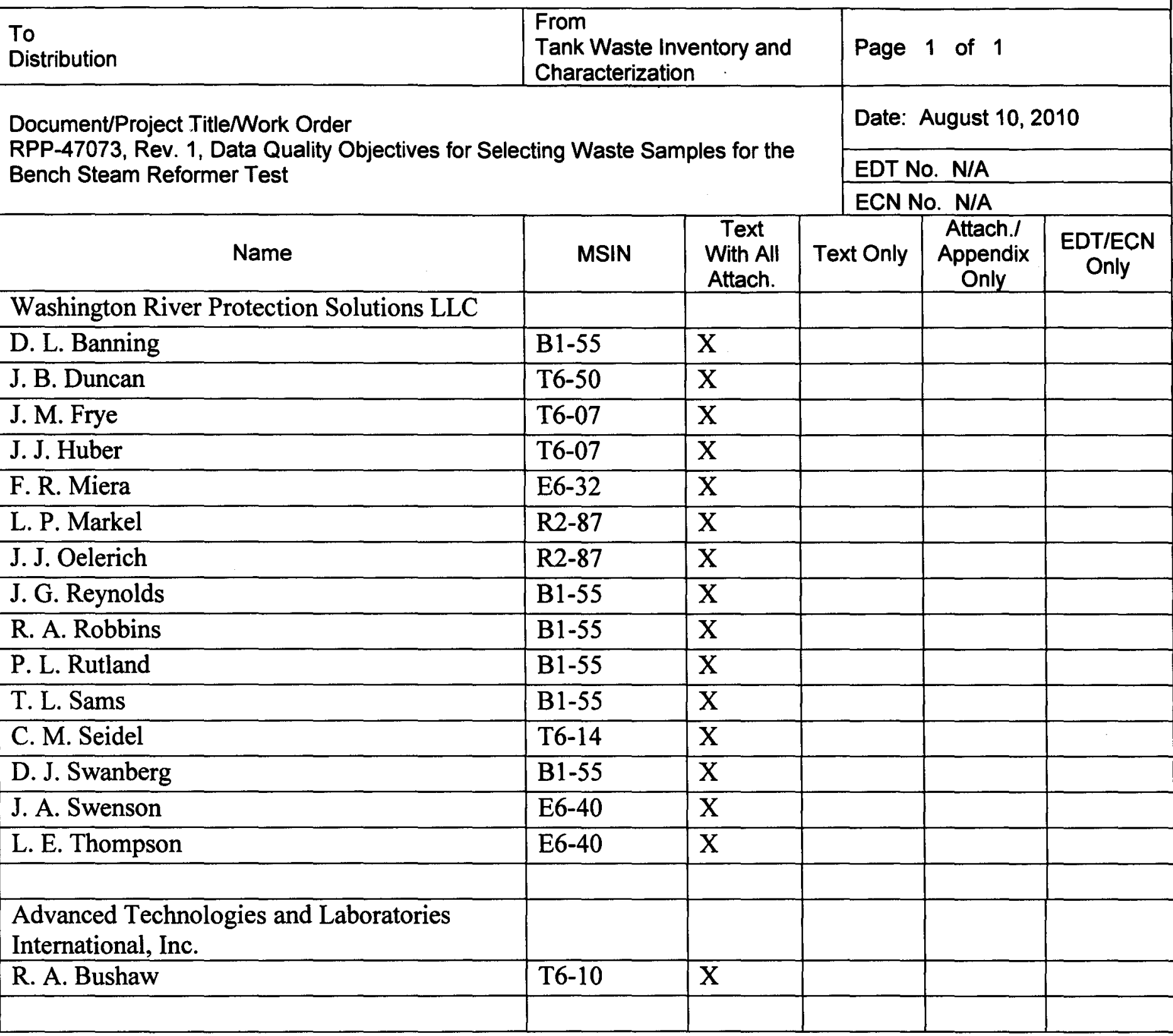

